\title{
ERRATUM
}

Susanne Juhnke $\cdot$ Nicola Peitzsch $\cdot$ Nicole Hübener

Cornelia Große · Dietrich H. Nies

\section{New genes involved in chromate resistance in Ralstonia metallidurans strain CH34}

Published online: 20 March 2004

(C) Springer-Verlag 2004

\section{Arch Microbiol (2002) 179:15-25}

During preparation of the Ph.D. thesis of Susanne Juhnke, we discovered that we accidentally compressed the data sets (Tables 1 and 3 ) for the genes $c h r F_{2}$ and $c h r R$ into one data set, which was assigned to $c h r F_{2}$. The corrected versions of Tables 1 and 3 are given below. chrR is a new gene not present in the genome annotation of Ralstonia metallidurans. It is located upstream of $c h r B_{2}$ on the opposite DNA strand of the chromosome of this bacterium. A revised version of Table W2 of the Electronic Supplementary Material is also available.

Table 1 Minimal inhibitory concentrations. Cells of Ralstonia metallidurans strain AE126(pMOL28) and its plasmid-free derivate strain AE104 were cultivated on solidified Tris-buffered mineral salts medium containing either $3 \mathrm{mM}$ sodium sulfate or $30 \mu \mathrm{M}$ sulfate and various concentrations of potassium chromate. Growth was analyzed after 3 days at $30^{\circ} \mathrm{C}$. Each determination was done at least three times with identical results

\begin{tabular}{llll}
\hline $\begin{array}{l}\text { Bacterial } \\
\text { strain }\end{array}$ & $\begin{array}{l}\text { Relevant } \\
\text { genotype }\end{array}$ & \multicolumn{2}{c}{ MIC values $(\mu \mathrm{M}$ of chromate $)$} \\
\cline { 3 - 4 } & & 3 mM Sulfate & $30 \mu$ M Sulfate \\
\hline AE126 & pMOL28 & 350 & 40 \\
& $\Delta c h r B_{1}$ & 350 & 40 \\
& $\Delta r p o H$ & 350 & 40 \\
& $\Delta c h r C$ & 300 & 35 \\
& $\Delta c h r I$ & 300 & 35 \\
AE104 & Plasmid-free & 150 & 20 \\
& $\Delta c h r F_{2}$ & 125 & 20 \\
& $\Delta c h r R$ & 175 & 20 \\
& $\Delta c h r B_{2}$ & 70 & 10 \\
& $\Delta c h r A_{2}$ & 70 & 10 \\
\hline
\end{tabular}

The online version of the original article can be found at http://dx.doi.org/10.1007/s00203-002-0492-5

\footnotetext{
S. Juhnke · N. Peitzsch · N. Hübener · C. Große · D. H. Nies $(\bowtie)$ Institut für Mikrobiologie,

Martin-Luther-Universität Halle-Wittenberg,

Kurt-Mothes-Strasse 3, 06099 Halle, Germany,

European Community,

Tel.: +49-345-5526352, Fax: +49-345-5527010,

e-mail: d.nies@mikrobiologie.uni-halle.de
}

Table 3 Activity of $c h r$ promoters in mutant strains of $R$. metallidurans. Cells were grown in Tris-buffered mineral salts medium containing either $3 \mathrm{mM}$ or $30 \mu \mathrm{M}$ sulfate and $2 \mathrm{~g}$ sodium gluconate/l with shaking at $30^{\circ} \mathrm{C}$ and the basal level of $\beta$-galactosidase activity from a $\operatorname{chr} A p_{1}: \because l a c Z$ or a $\operatorname{chrB} p_{1}: \because l a c Z$ fusion was determined. Half of the culture was induced with $50 \mu \mathrm{M}$ chromate ( $3 \mathrm{mM}$ sulfate) or $20 \mu \mathrm{M}$ chromate $(30 \mu \mathrm{M}$ sulfate) and incubation was continued with shaking for $3 \mathrm{~h}$ at $30^{\circ} \mathrm{C}$. The chromate concentrations used were the optimum inducer concentration at the respective sulfate concentration (Fig. 3). $\beta$-Galactosidase activity was determined in the uninduced control and divided by the basal level expression leading to $\mathrm{IR}_{\text {unind. }}$. Similarly, $\beta$-galactosidase activity was determined in the induced cells and also divided by the basal level expression leading to $\mathrm{IR}_{\text {ind }}$. The induction ratio $\mathrm{IR}_{\mathrm{ind}}$ was divided by the control ratio $\mathrm{IR}_{\text {unind }}$. All points were done in triplicate in each experiment. Moreover, each experiment was done at least three times independently, and the standard deviations of these three experiments are shown. nd Not determined. Table W2 of the electronic supplementary material has an extended version of this table that contains the $\mathrm{IR}_{\text {ind }}$, the $\mathrm{IR}_{\text {unind }}$ and the basal level expression data

\begin{tabular}{|c|c|c|c|}
\hline Promoter & $\begin{array}{l}\text { Genetic } \\
\text { background }\end{array}$ & $\begin{array}{l}\mathrm{IR}_{\text {ind }} / \mathrm{IR}_{\text {unind }} \\
50 \mu \mathrm{MrO}_{4}{ }^{2-} \\
3 \mathrm{mM} \mathrm{SO}_{4}{ }^{2-}\end{array}$ & $\begin{array}{l}\mathrm{IR}_{\text {ind }} / \mathrm{IR}_{\text {unind }} \\
20 \mu \mathrm{M} \mathrm{CrO}_{4}{ }^{2-} \\
30 \mu \mathrm{M} \mathrm{SO}{ }_{4}^{2-}\end{array}$ \\
\hline \multirow[t]{4}{*}{ chrAp } & pMOL28 & 0.91 & n. d. \\
\hline & $\Delta c h r B_{1}$ & 0.91 & n. d. \\
\hline & $\Delta c h r I$ & 0.93 & n. d. \\
\hline & No pMOL28 & 1.04 & n. d. \\
\hline \multirow[t]{9}{*}{$\operatorname{chrBp}$} & pMOL28 & 4.88 & 1.90 \\
\hline & $\Delta c h r B_{1}$ & 4.46 & 3.24 \\
\hline & $\Delta c h r I$ & 4.32 & 5.52 \\
\hline & $\Delta c h r C$ & 10.4 & 1.83 \\
\hline & $\Delta r p o H$ & 15.1 & 9.42 \\
\hline & No pMOL28 & 2.20 & 1.77 \\
\hline & $\Delta c h r B_{2}$ & 1.02 & 1.03 \\
\hline & $\Delta c h r F_{2}$ & 2.50 & 1.70 \\
\hline & $\Delta c h r R$ & 10.5 & 3.84 \\
\hline
\end{tabular}

